\title{
REFORMULASI BEBAN PEMBUKTIAN TERBALIK BERLANDASKAN ASAS PRESUMPTION OF GUILT TERHADAP KASUS TPPU DI INDONESIA
}

\author{
Vicko Taniady*, Novi Wahyu Riwayanti \\ Universitas Jember \\ *Correspondent Email : taniadivicko5@gmail.com
}

Naskah diterima: 29/10/2021, Revisi: 15/11/2021, Disetujui: 31/12/2021

\begin{abstract}
Abstrak
Tindak Pidana Pencucian Uang (TPPU) sebagai tindak pidana transnasional membawa dampak kerugian terhadap negara yang sangat besar. Salah satu kebijakan untuk meminta pertanggungjawaban terhadap terdakwa adalah menggunakan beban pembuktian terbalik. Tujuan penelitian ini adalah untuk mengkaji mekanisme beban pembuktian terbalik yang saat ini berlaku, serta menganalisis untuk melakukan reformulasi beban pembuktian terbalik berlandaskan asas presumption of guilt. Metode penelitian yang digunakan adalah hukum normatif dengan pendekatan peraturan perundang-undangan (statute approach) dan kasus (case approach), serta menggunakan teknik studi pustaka dalam mengolah data sekunder. Hasil penelitian ini menunjukkan pola beban pembuktian terbalik pada UU TPPU masih mengalami problematika terkhusus dalam hal asset recovery. Selain itu, mekanisme beban pembuktian terbalik dalam UU TPPU belum mengatur prosedur terkait beracaranya atau setidak-tidaknya terkait mengatur konsekuensi dari pembuktian terbalik tersebut. Melihat hal tersebut, penerapan beban pembuktian terbalik berlandaskan asas presumption of guilt dalam kasus TPPU menjadi urgensi yang harus dilakukan. Beban pembuktian terbalik berlandaskan asas presumption of guilt akan menggunakan dua metode yakni criminal forfeiture dan civil forfeiture, sehingga mampu lebih optimal dalam melakukan asset recovery. Adanya asas beban pembuktian terbalik yang berlandaskan asas presumption of guilt diharapkan mampu untuk meminimalisir kesulitan dalam mekanisme pembuktian TPPU..
\end{abstract}

Kata Kunci: Asas Presumption of Guilt, Beban Pembuktian Terbalik, TPPU

\section{PENDAHULUAN}

1. Latar Belakang

How to cite:

Taniady, V \& Riwayanti, N.W. (2021). "Reformulasi Beban Pembuktian Terbalik Berlandaskan Asas Presumption of Guilt terhadap Kasus TPPU di Indonesia". Ikatan Penulis Mahasiswa Hukum Indonesia Law Journal, 1(2).

Diterbitkan oleh:

Ikatan Penulis Mahasiswa Hukum Indonesia

IPMHI Law Journal

${ }^{\circ} 2021$ Author 
Tindak Pidana Pencucian Uang (selanjutnya disebut TPPU) merupakan kejahatan tindak pidana ekonomi yang berdimensi sebagai kejahatan transnasional. ${ }^{1}$ TPPU merupakan kejahatan baru yang terjadi dibanyak negara, termasuk di Indonesia. TPPU dapat diartikan sebagai kegiatan untuk memindahkan atau menggunakan hasil tindak pidana yang bertujuan untuk menghilangkan hasil tindak pidana tersebut. Berdasarkan pandangan Profesor Sutan Remy Sjahdaeni, TPPU diartikan sebagai kegiatan yang diperbuat oleh seseorang maupun organisasi terhadap uang yang berasal dari kejahatan dengan maksud untuk menyembunyikan dan menghilangkan asal mula uang tersebut sehingga uang tersebut selanjutnya dapat dikeluarkan sebagai uang halal. ${ }^{2}$ Perkembangan TPPU juga semakin pesat melihat pasar globalisasi yang begitu luas. Dampak tersebut memberikan pihak terkait untuk melakukan streril investment baik di bidang properti dan lainnya semakin mudah dan memberikan dampak negatif bagi perekonomian suatu negara.

Berdasarkan data Pusat Pelaporan dan Analisis Transaksi Keuangan (PPATK) pada Januari 2005 hingga Juni 2020, jumlah putusan pengadilan terkait TPPU mencapai 426 kasus dengan hukuman maksimal penjara seumur hidup serta denda maksimal Rp32 miliar. ${ }^{3}$ Kemudian, berdasarkan data Komisi Pemberantasan Korupsi (KPK) dari tahun 2012 hingga September 2021, terdapat sebanyak 38 kasus TPPU. ${ }^{4}$ United Nations Convention Against Corruption 2003 (UNCAC) juga mengimbau kepada negara anggota untuk mengambil tindakan preventif melalui hukum nasionalnya serta memiliki kewajiban untuk mengadopsi sesuai dengan prinsip hukum nasionalnya untuk memerangi kegiatan yang digolongkan ke dalam TPPU. ${ }^{5}$ Hal tersebut kemudian sejalan dengan dikeluarkannya beberapa pengaturan pertanggungjawaban TPPU oleh pemerintah Indonesia.

Penulis dalam hal ini akan mengkaji lebih lanjut Undang-Undang Nomor 8 Tahun 2010 tentang Pencegahan dan Pemberantasan Tindak Pidana Pencucian Uang (selanjutnya disebut UU TPPU) sebagai instrumen hukum utama dalam menyelesaikan kasus TPPU. UU TPPU juga telah mencakup subjek hukum individu maupun korporasi sebagaimana tertuang dalam Pasal 1 Angka 9 UU TPPU. Namun, masih terdapat persoalan di dalam UU TPPU terkhusus dalam melakukan asset recovery serta optimalisasi terhadap pertanggungjawaban pidana. Hal tersebut dapat dilihat pada tahun 2018, bahwa aset yang berhasil diselamatkan

$1 \quad$ Marcel Kordos and Sergej Vojtovic, "Transnational Corporations in the Global World Economic Environment," Procedia - Social and Behavioral Sciences 230, no. May (2016): 150158, hlm 151.

2 Julita, "Strategi Pencegahan Money Laundering Melalui Know Your Customer Principles Pada Bank Muamalat Cabang Purwokerto" (IAIN Purwokerto, 2021), http://repository.iainpurwokerto.ac.id/9450/, hlm 1.

3 Pusat Pelaporan dan Analisis Transaksi Keuangan, Buletin Statistik Tahun 2020 Anti Pencucian Uang Dan Pencegahan Pendanaan Terorisme (Jakarta, 2020), https://www.ppatk.go.id/publikasi/read/120/buletin-statistik-apuppt-vol-124---juni-2020.html, hlm 45 .

$4 \quad$ Komisi Pemberantasan Korupsi, "Statistik TPK Berdasarkan Jenis Perkara," last modified 2021, accessed September 23, 2021, https://www.kpk.go.id/id/statistik/penindakan/tpkberdasarkan-jenis-perkara.

$5 \quad$ Muhamad Mahrus Setia Wijaksana, "Ajaran Pertanggungjawaban Pidana Korporasi Dalam Perspektif Tindak Pidana Pencucian Uang," Jurnal RechtsVinding: Media Pembinaan Hukum Nasional (2020): 1-6, https://rechtsvinding.bphn.go.id/jurnal_online/AJARAN PJP KORPORASI TPPU.pdf, hlm 1-2. 
pada tindak pidana korupsi hanya Rp222 milliar dari Rp7,62 trilliun. ${ }^{6}$ Oleh karena itu, konsep beban pembuktian terbalik menjadi sebuah urgensi yang harus dilakukan dalam pembuktian perkara TPPU.

Selanjutnya, di dalam Pasal 77 UU TPPU telah mengilhami untuk melakukan beban pembuktian terbalik di Indonesia. Akan tetapi, konsep beban pembuktian terbalik tersebut bersifat berimbang dan terbatas. ${ }^{7}$ Maksud dari berimbang adalah penuntut umum wajib untuk membuktikan dakwaannya sesuai asas actori incumbit probatio (siapa yang mendalilkan, maka wajib untuk membuktikan) ${ }^{8}$. Selain itu, maksud dari terbatas adalah penggunaan beban pembuktian terbalik dibatasi pada tindak pidana tertentu saja. ${ }^{9}$ Implementasi beban pembuktian terbalik di Indonesia juga kurang optimal sebab berbenturan terhadap asas presumption of innoncene.

Saat ini sudah diatur berbagai kebijakan dalam rangka mencegah serta memberantas tindak pidana pencucian uang dan pendanaan terorisme, khususnya berkaitan dengan proses penyidikan, penuntutan, hingga putusan pengadilan, serta upaya lain seperti pemblokiran, penyitaan, dan perampasan harta kekayaan yang diketahui atau patut diduga diperoleh dari hasil kejahatan. Namun, dalam keberjalanannya, aparat penyidik ${ }^{10}$ seringkali masih dihadapkan pada permasalahan berkenaan dengan sulitnya pembuktian unsur mens rea (unsur subjektif) maupun unsur objektif dalam tindak pidana pencucian uang, karena pendekatan yang digunakan selama ini cenderung berorientasi pada pengejaran aliran dana (follow the money).

Dengan demikian, maka penulis menggagas untuk mereformulasi beban pembuktian terbalik berlandaskan asas presumption of guilt, yang secara efektif akan merujuk pada pembuktian tindak pidana asal (predicate crime). ${ }^{11}$ Beban pembuktian terbalik berlandaskan asas presumption of guilt akan memiliki sifat tidak terbatas terhadap TPPU serta mengadopsi taint doctrine terhadap aset ternodai oleh TPPU.

\section{Perumusan Masalah}

1. Bagaimana Bagaimana mekanisme beban pembuktian terbalik pada UU TPPU di Indonesia?

2. Bagaimana penerapan beban pembuktian terbalik berlandaskan asas presumption of guilt terhadap kasus TPPU di Indonesia?

$\begin{array}{llccc}6 & \text { Bisnis.com, "Hari Antikorupsi: Total Kerugian Negara Sejak } 2018 \text { Capai Rp7,62 Triliun," } \\ \text { last } & \text { modified } & 2020, & \text { accessed } & \text { July }\end{array}$ https://kabar24.bisnis.com/read/20201210/15/1328940/hari-antikorupsi-total-kerugian-negarasejak-2018-capai-rp762-triliun\#: :text=Jumlah.

7 Ayu Komang Sari Merta Dewi and I Gusti Ayu Puspawati, "Penerapan Sistem Pembuktian Terbalik Terhadap Tindak Pidana Korupsi (Sebuah Upaya Progresif Dalam Pemberantasan Tindak Pidana Korupsi)," Yustisia Jurnal Hukum 1, no. 2 (2012): 1-5, hlm 3.

Hariman Satria, "Ke Arah Pergeseran Beban Pembuktian," Integritas Jurnal Anti Korupsi 3, no. 1 (2017): 87-114, hlm 90.

Dewi and Puspawati, "Penerapan Sistem Pembuktian Terbalik Terhadap Tindak Pidana Korupsi (Sebuah Upaya Progresif Dalam Pemberantasan Tindak Pidana Korupsi).” hlm 3.

${ }^{10}$ Putusan Mahkamah Agung Nomor 15/PUU-XIX/2021 tentang Permohonan Pengujian UndangUndang Nomor 8 Tahun 2010 tentang Pencegahan dan Pemberantasan Tindak Pidana Pencucian Uang terhadap Undang-Undang Dasar Negara Republik Indonesia Tahun 1945.

11 Ida Ayu Setyawati, "Beban Pembuktian Terbalik Dalam Perkara Money Laundering Dengan Predicate Crime Tindak Pidana Korupsi” Februari (2014): 1-19, http://hukum.studentjournal.ub.ac.id/index.php/hukum/article/view/375, hlm 1. 
3. Bagaimana solusi zonasi, transformasi, dan reformasi e-Litigasi pidana dapat diterapkan dan menjamin due process of law?

\section{METODE}

Metode penelitian yang digunakan adalah dengan penelitian hukum normatif serta menggunakan pendekatan peraturan perundang-undangan (statue approach) dan pendekatan kasus (case approach). Kemudian, jenis data yang digunakan meliputi bahan hukum primer seperti peraturan perundang-undangan yang berkaitan dengan TPPU, bahan hukum sekunder, dan bahan hukum tersier. Dari bahan-bahan hukum tersebut, maka akan diinventarisir oleh penulis dengan menggunakan metode studi kepustakaan untuk mendapatkan preskripsi atas isu hukum yang diangkat. Penulis lalu akan menggunakan analisa data menggunakan pola deduksi untuk menjelaskan berbagai norma pertauran yang berkaitan dengan isu hukum terlebih dahulu kemudian menjelaskan tentang fakta hukum. Analisa data tersebut disusun secara sistematis, teratur, logis, seksama, dan dideskripsikan secara holistik dan rinci. Dengan demikian, pola penalaran tersebut disusun secara sistematis sehingga tercapai suatu kesimpulan dari isu hukum yang dikaji.

\section{HASIL PENELITIAN DAN PEMBAHASAN \\ 1. MEKANISME BEBAN PEMBUKTIAN TERBALIK PADA UU TPPU DI INDONESIA}

Permasalahan TPPU yang semakin kompleks mengakibatkan sistem pembuktian yang dirancang KUHAP melemah. ${ }^{12}$ Akibatnya, banyak kasus TPPU yang lolos dari jerat hukum karena sistem pembuktian yang susah dilaksanakan. Hadirnya UU TPPU yang mencoba menerapkan beban pembuktian terbalik membawa angin segar bagi reformasi penegakan TPPU. Disisi lain, beban pembuktian terbalik menuai kontradiksi karena bertentangan dengan asas praduga tak bersalah (presumption of innocence), asas persamaan dihadapan hukum (equality before the law), asas pemeriksaan akusator dan prinsip "privilege against self-incrimination".

Asas beban pembuktian terbalik terejawantahkan ke dalam Pasal 77 UU TPPU yang mengatakan bahwa terdakwa wajib membuktikan harta kekayaannya bukan merupakan hasil dari tindak pidana. Ketentuan tersebut yang kemudian dipertegas kembali di dalam Pasal 78 UU TPPU bahwa hakim memerintahkan agar terdakwa membuktikan harta kekayaannya yang terkait dengan perkara, bukan berasal atau terkait dengan tindak pidana sebagaimana dimaksud dalam Pasal 2 Ayat (1) UU TPPU.

Dari ketentuan-ketentuan tersebut, maka asas pembuktian terbalik dalam UU TPPU menganut sistem beban pembuktian terbalik terbatas dan berimbang. Artinya, terdakwa disini hanya perlu membuktikan bahwa harta kekayaannya bukan merupakan hasil tindak pidana, sedangkan jaksa penuntut umum yang harus tetap membuktikan unsur-unsur kesalahan terdakwa. Konsekuensi yuridis apabila terdakwa tidak dapat membuktikan harta kekayaannya merupakan harta bersih (bukan berasal dari tindak pidana), maka tidak berarti perbuatan yang didakwakan kepada terdakwa, terdakwa terbukti melakukan tindak pidana. Hal tersebut dikarenakan pembuktian

\footnotetext{
12 Apri Listiyanto, "Pembaharuan Sistem Hukum Acara Pidana," Rechtsvinding (2017): 1-4, https://rechtsvinding.bphn.go.id/view/view_online.php?id=234, hlm 2.
} 
tersebut hanya terkait dengan salah satu unsur mengenai asal usul harta kekayaannya. ${ }^{13}$ Logisnya, dari beban pembuktian terbalik akan mendapatkan hasil tindak pidana asal terjadinya pencucian uang.

Ketentuan Pasal 2 UU TPPU di atas secara eksplisit telah membatasi penuntut umum agar selektif dalam menentukan harta kekayaan yang wajib atau tidak wajib dibuktikan oleh terdakwa. ${ }^{14}$ Ketentuan tersebut menunjukkan bahwa UU TPPU masih memiliki kekurangan dalam menyikapi mekanisme perampasan terhadap harta kekayaan yang tidak ikut dirampas dalam proses pidana, karena hanya harta kekayaan yang tercantum dalam surat dakwaan penuntut umum saja yang wajib dibuktikan oleh terdakwa.

\section{PENERAPAN BEBAN PEMBUKTIAN TERBALIK BERLANDASKAN ASAS PRESUMPTION OF GUILT TERHADAP KASUS TPPU DI INDONESIA}

Melihat problematika dalam penerapan beban pembuktian terbalik yang saat ini diilhami dalam UU TPPU, maka diperlukannya urgensi untuk melakukan reformulasi sehingga mampu bersifat asset recovery dan tetap mempertahankan pertanggungjawaban pidana. Penerapan asas presumption of guilt sejatinya dapat menjadi jawaban dari problematika yang ada. Akan tetapi, asas presumption of guilt ini tidak terakomodir di dalam KUHAP sehinga perlu menjadikan asas praduga bersalah tersebut sebagai ius constituendum dan bersifat lex specialist. Dengan diadopsinya sistem pembuktian terbalik berlandaskan asas presumption of guilt dengan lex specialist, maka hakim memiliki kewenangan absolute untuk memerintahkan terdakwa wajib membuktikan seluruh harta kekayaannya bukan berasal hasil tindak pidana.

Proses penyelesaian TPPU berlandaskan asas presumption of guilt selaras dengan penyelesaian perkara pidana crime control model dan due process model. Penerapan crime control model sendiri bertujuan untuk menekan tindak kriminal sebagai fungsi terpenting dari suatu proses penyelesaian tindak pidana sehingga metode ini sangat mengedepankan efisiensi. Penempatan karakter crime control model melalui tindakan reprepresif terhadap seorang penjahat merupakan fungsi terpenting dari suatu proses peradilan, sehingga proses peradilan bertumpu kepada kualitas temuan fakta administratif yang berguna bagi pembebasan seorang tersangka dari penuntutan atau kesediaan tersangka menyatakan dirinya bersalah (Plead of guilty). Sedangkan pada metode due process model, persamaannya terletak pada mengedepankan prosedur dalam penyelesaian perkara dengan membatasi kekuasaan pemerintah dan melindungi hak asasi manusia dari potensi terjadinya kesewenang-wenangan. Dalam penerapan asas presumption of guilt sendiri beban pembuktian terbalik tidak dilakukan secara overall, tetapi memiliki batas-batas yang seminimal mungkin tidak melakukan suatu desktruksi terhadap perlindungan dan penghargaan HAM, khususnya hak tersangka atau terdakwa.

Beban pembuktian terbalik yang disertai asas presumption of guilt akan dapat menerangkan asal-usul harta kekayaan terdakwa disertai dengan

13 Maria Silvya E. Wangga, "Mekanisme Pembalikan Beban Pembuktian Tindak Pidana Pencucian Uang," Jurnal Hukum 3, no. 2 (2012): 333-352, hlm 344.

14 Romi Atmasasmita, Sistem Peradilan Pidana Kontemporer (Jakarta: Kencana Prenada Media Group, 2011), hlm 19. 
bukti-bukti yang menjelaskan kapan, darimana, dan bagaimana cara memperoleh harta kekayaannya.Oleh karena itu, perlu adanya perubahan orientasi penanganan tindak pidana, yaitu dari pendekatan follow the suspect (menangkap dan memidanakan pelaku tindak pidana) menjadi follow the money, yaitu sebuah pendekatan dari hilir keberadaan harta kekayaan yang kemudian direkonstruksi sampai ke hulu menemukan tindak pidana yang melahirkan harta kekayaan.

Penerapan beban pembuktian terbalik berlandaskan asas presumption of guilt juga akan dapat dijadikan landasan dalam penyitaan harta kekayaan yang berkaitan dengan kejahatan. Hal tersebut dikarenakan pengembalian aset TPPU di Indonesia masih akan dilakukan pada saat setelah putusan pengadilan. Artinya, perampasan asset hasil kejahatan hanya dapat dilaksanakan setelah pelaku tindak pidana terbukti di pengadilan secara sah dan meyakinkan melakukan tindak pidana berdasarkan putusan pengadilan yang telah memiliki kekuatan hukum tetap (inkracht van gewisjde). Proses perampasan aset terkait dengan hasil kejahatan dimulai dari adanya laporan dari pihak pelapor mengenai adanya transaksi keuangan mencurigakan yang telah diatur dalam Pasal 1 angka 5 UU TPPU.

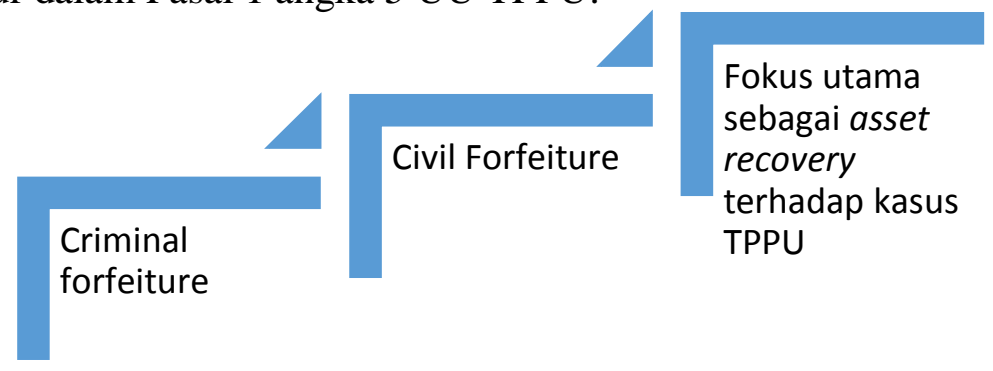

\section{Gambar 4. 2. Penerapan Beban Pembuktian Terbalik Berlandaskan Asas Presumption of Guilt Melalui Criminal and Civil Forfeiture}

Pengembalian aset (asset recovery) hasil TPPU melalui beban pembuktian terbalik berlandaskan asas presumption of guilt dapat dilakukan melalui jalur criminal forfeiture dan civil forfeiture. ${ }^{15}$ Proses pengembalian asset melalui criminal forfeiture di Indonesia dilakukan melalui empat (4) tahap, yaitu: ${ }^{16}$ pertama dengan melakukan pelacakan asal usul asset sehingga dapat diidentifikasi kapasitas hubungan dengan delik/tindak pidana yang dilakukan. Kedua, pembekuan atau perampasan aset dimana menurut UNCAC 2003 Bab I Pasal 2 huruf f aspek ini ditentukan meliputi larangan sementara untuk mentransfer, mengkonversi, mendisposisi, atau memindahkan kekayaan atau untuk sementara menanggung beban dan tanggung jawab mengurus dan memelihara serta mengawasi kekayaan berdasarkan penetapan pengadilan atau penetapan dari otoritas lain yang berkompeten. Ketiga, penyitaan aset dimana menurut Bab I Pasal 2 huruf g UNCAC 2003 diartikan sebagai pencabutan kekayaan untuk selamanya

15 A.A Mirah Endraswari, "Penerapan Beban Pembuktian Terbalik Dalam Perampasan Illicit Enrichment Kaitannya Dengan Hak Asasi Manusia," Jurnal Magister Hukum Udayana (Udayana Master Law Journal) 5, no. 2 (July 31, 2016): 392-405, hlm 395.

16 Ramelan et al., Laporan Akhir Naskah Akademik Rancangan Undang-Undang Tentang Perampasan Aset Tindak Pidana, hlm 23. 
berdasarkan penetapan pengadilan atau otoritas lain yang berkompeten. Keempat, pengembalian dan penyerahan aset-aset kepada negara yang menjadi korban. Sejatinya metode tersebut sangat efektif untuk diterapkan dalam TPPU. Namun, UU TPPU tidak mengatur secara terperinci subtansi terkait tata cara pelaksanaan pengembalian kerugian keuangan negara dengan uang pengganti secara lebih terperinci dan tersendiri.

Pada kasus civil forfeiture, pemerintah melakukan gugatan perdata terpisah in rem terhadap harta kekayaan yang akan dirampas, dan harus dapat mengajukan bukti-bukti yang lebih kuat bahwa harta kekayaan tersebut dihasilkan atau digunakan untuk melakukan tindak pidana. ${ }^{17}$ Gugatan ini dapat diajukan sebelum putusan pidana, sesudah putusan pidana, atau bahkan sekalipun tidak terdapat putusan pidana menyangkut tindak pidana tersebut. Pengembalian asset dengan adanya sistem pembuktian terbalik dengan asas presumption of guilt lebih mudah dilakukan, karena pengembalian aset hasil dari tindak pidana dilakukan secara perdata. Seperti halnya negara Amerika, Inggris dan negara Eropa lainnya sudah menggunakan jalur keperdataan dalam pengembalian aset hasil dari tindak pidana pencucian uang. Terdapat beberapa keunggulan melalui beban pembuktian terbalik civil forfeiture berlandaskan asas presumption of guilt, yakni.

\begin{tabular}{|c|l|l|}
\hline No. & \multicolumn{1}{|c|}{ Keunggulan } & Penjelasan \\
\hline 1. & $\begin{array}{l}\text { civil forfeiture tidak } \\
\text { berkaitan dengan } \\
\text { sebuah tindak pidana. }\end{array}$ & $\begin{array}{l}\text { Dengan tidak adanya keterkaitan dengan } \\
\text { tindak pidana, namun mengedepankan } \\
\text { asset recovery, proses penyitaan dapat } \\
\text { dilakukan dengan cepat, tanpa adanya } \\
\text { putusan pengadilan. Sehingga, apabila } \\
\text { pemerintah menduga adanya aset yang } \\
\text { ternodai maka dapat dilakukan } \\
\text { pemeriksaan. }\end{array}$ \\
\hline 2. & $\begin{array}{l}\text { civil forfeiture } \\
\text { menggunakan } \\
\text { prosedur pembuktian } \\
\text { perdata }\end{array}$ & $\begin{array}{l}\text { Melalui prosedur pembuktian perdata relatif } \\
\text { ringan untuk dipenuhi. Selain itu, dengan } \\
\text { mengadopsi beban pembuktian terbalik } \\
\text { civil forfeiture akan mampu meringankan } \\
\text { penegak hukum dalam proses pembuktian }\end{array}$ \\
\hline 3. & $\begin{array}{l}\text { civilforfeiture bersifat } \\
\text { in rem. }\end{array}$ & $\begin{array}{l}\text { Gugatan yang diajukan hanya berurusan } \\
\text { dengan aset yang diduga dihasilkan dan } \\
\text { terlibat dalam tindak pidana. Selain itu, } \\
\text { adanya pengkabur gugatan (Terdakwa } \\
\text { meninggal, bebasnya koruptor, tidak cukup } \\
\text { bukti, dan lainnya) tidak } \\
\text { membuat gugatan berhenti. }\end{array}$ \\
\hline
\end{tabular}

17 European Union and The Council of Europe, Impact Study on Civil Forfeiture (Council of Europe, 2013), hlm 23-29. 


\begin{tabular}{|l|l|l|}
\hline 4. & $\begin{array}{l}\text { civil forfeiture dapat } \\
\text { berguna terhadap }\end{array}$ & $\begin{array}{l}\text { Sebagaimana yang kita ketahui, adanya } \\
\text { politically well-connected yang dilakukan } \\
\text { kasus yang } \\
\text { oleh koruptor membuat para penegak }\end{array}$ \\
mendapatkan & $\begin{array}{l}\text { hukum mengalami kesulitan untuk } \\
\text { halangan atau tidak } \\
\text { memungkinkan untuk } \\
\text { dilaksanakan. }\end{array}$ & $\begin{array}{l}\text { berfokus terhadap aset, memungkinkan } \\
\text { meminimalisir political and social cost } \\
\text { tuntutan pidananya. }\end{array}$ \\
\end{tabular}

\section{Tabel 4. 1. Keunggulan Melalui Beban Pembuktian Terbalik Civil} Forfeiture berlandaskan Asas Presumption of Guilt.

Adanya asas beban pembuktian terbalik yang berlandaskan asas presumption of guilt diharapkan mampu untuk meminimalisir kesulitan dalam mekanisme pembuktian TPPU. Sehingga terdakwa tidak dapat lagi berlindung dibalik asas praduga tak bersalah (presumption of innocence) yang selama ini telah melindungi tindak pidana pencucian dari jeratan hukum pidana.
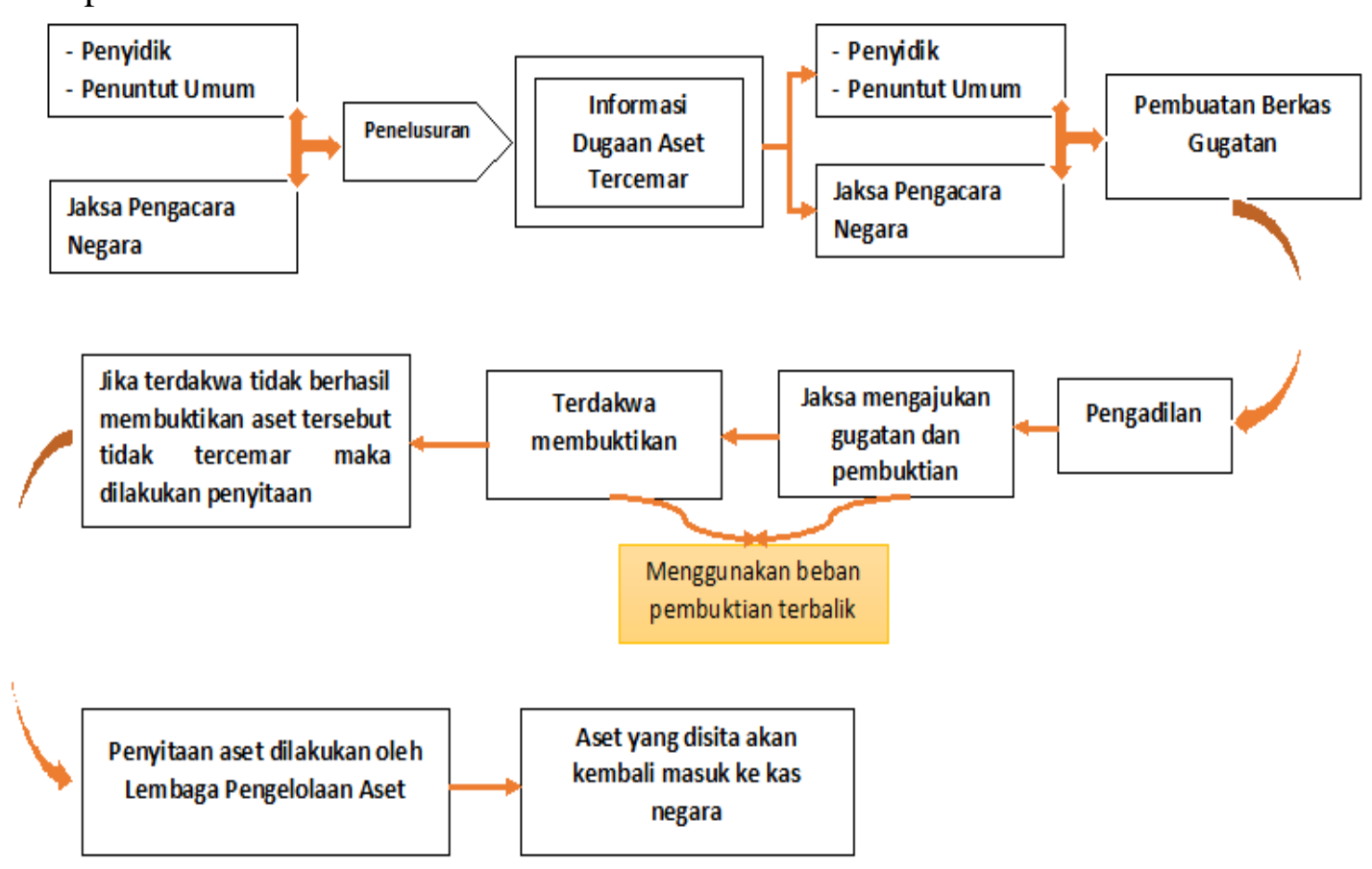

\section{Gambar 4. 3. Penerapan Beban Pembuktian Terbalik Berlandaskan Asas Presumption of Guilt yang Diharapkan}

Dalam melakukan reformulasi beban pembuktian terbalik berlandaskan asas presumption of guilt, maka diperlukannya dasar hukum yang jelas untuk mengatur serta mengimplementasikan tersebut. Maka diperlukannya upaya untuk melakukan revisi dari beberapa peraturan di Indonesia yang akan dijelaskan melalui tabel berikut:

\begin{tabular}{|c|l|l|}
\hline No. & \multicolumn{1}{|c|}{ Peraturan } & \multicolumn{1}{c|}{ Penjelasan } \\
\hline 1. & UU TPPU & $\begin{array}{l}\text { Perlu adanya pengadopsian yang lebih } \\
\text { jelas terkait beban pembuktian terbalik }\end{array}$ \\
\hline
\end{tabular}




\begin{tabular}{|c|l|l|}
\hline & & $\begin{array}{l}\text { berlandaskan asas presumption of guilt } \\
\text { dengan skema criminal forfeiture dan } \\
\text { civil forfeiture. }\end{array}$ \\
\hline 2. & KUHAP & $\begin{array}{l}\text { Mengatur jalannya hukum acara beban } \\
\text { pembuktian terbalik berlandaskan asas } \\
\text { presumption of guilt. }\end{array}$ \\
\hline 3. & UU Kejaksaan & $\begin{array}{l}\text { Pengaturan lebih jelas terhadap } \\
\text { kejaksaan dalam menangani serta } \\
\text { mengimplementasikan beban } \\
\text { pembuktian terbalik berlandaskan asas } \\
\text { presumption of guilt }\end{array}$ \\
\hline
\end{tabular}

Tabel 4. 2. Usulan Revisi Peraturan Perundang-Undangan.

\section{SIMPULAN DAN SARAN}

\section{A. Kesimpulan}

Beban pembuktian terbalik sejatinya telah diatur secara eksplisit pada Pasal 77 dan 78 UU TPPU. Konsekuensi yuridis dari adanya pasal tersebut adalah terdakwa dituntut untuk membuktikan asal-usul harta yang diduga oleh penuntut umum sebagai harta yang diperoleh melalui tindak pidana. Mengenai harta yang dapat dipersangkakan sebagai harta hasil tindak pidana telah diatur secara rinci dalam Pasal 2 UU TPPU. Dimana ketentuan ini secara langsung telah membatasi penuntut umum agar selektif dalam menentukan harta kekayaan yang wajib atau tidak wajib dibuktikan oleh terdakwa. Akan tetapi, UU TPPU belum mengakomodir terkait bagaimana prosedur beracaranya atau mengatur mengenai konsekuensi dari pembuktian terbalik tersebut. Oleh karena itu perlu adanya reformulasi terkait pengaturan beban pembuktian terbalik pada UU TPPU.

Dengan adanya penerapan beban pembuktian terbalik berlandaskan asas presumption of guilt sebagai landasan penggunaan asas pembalikan beban pembuktian yang tidak diatur dalam KUHAP, membawa dampak lex specialist pada UU TPPU. Akibatnnya, hakim memiliki kewenangan mutlak untuk memerintahkan terdakwa mewajibkan membuktikan seluruh harta kekayaannya bukan berasal hasil tindak pidana. Penggunaan asas presumption of guilt juga selaras dengan metode penyelesaian perkara pidana secara crime control model dan due process model sehingga asas presumption of guilt tidaklah illegal untuk digunakan. Selain itu dengan sistem pembalikan beban pembuktian yang dilaksanakan secara terbatas dan berimbang tidaklah melanggar hak asasi manusia. Asset Recovery sebagai tujuan dari adanya pembalikan beban pembuktian juga akan lebih mudah dilaksakan apabila menggunakan asas presumption of guilt. Hal ini dikarenakan penerapan beban pembuktian terbalik akan bersifat criminal forfeiture dan civil forfeiture. Melalui hal tersebut, perampasan dapat dilakukan sebelum putusan pidana, sesudah putusan pidana, atau bahkan sekalipun tidak terdapat putusan pidana menyangkut tindak pidana tersebut.

\section{B. Saran}


Pertama, perlu adanya upaya revisi peraturan perundang-undangan yang meliputi UU TPPU, KUHAP, dan UU Kejaksaan. Melalui revisi UU TPPU, diharapkan mampu menjadi dasar hukum yang pasti dalam menerapkan beban pembuktian terbalik berlandaskan asas presumption of guilt. Selain itu upaya untuk revisi KUHAP dan UU Kejaksaan adalah untuk menjadi hukum acara baik bagi penyidik dan penuntut umum dalam memeriksa hingga membuktikan perkara TPPU di Indonesia; Kedua, perlu adanya urgensi pengesahan Rancangan Undang-Undang Perampasan Aset Tindak Pidana. Melalui pengesahan rancangan undang-undang tersebut, mampu memperkuat penerapan beban pembuktian terbalik berlandaskan asas presumption of guilt yang lebih menyasar follow the money dan asset recovery; Ketiga, perlu adanya upaya sinergritas penegak hukum, baik kepolisian, penuntut umum, PPATK, hingga hakim, untuk mampu menjalankan serta menerapkan beban pembuktian terbalik berlandaskan asas presumption of guilt yang juga menghormati HAM; dan Keempat, perlu adanya penguatan sistem pelacakan uang dari PPATK dan penguatan peran PPATK dalam penyelidikan dan penututan TPPU.

\section{DAFTAR PUSTAKA}

\section{Buku}

Atmasasmita, R. (2011) Sistem Peradilan Pidana Kontemporer. Jakarta: Kencana Prenada Media Group.

Hiariej, Eddy O.S. (2012). Teori Dan Hukum Pembuktian. Jakarta : Erlangga.

Imron, A \& Iqbal, M. (2019). Hukum Pembuktian. Tanggerang Selatan: Unpam Press.

Nugrahani, F. (2014). Metode Penelitian Kualitatif Dalam Penelitian Pendidikan Bahasa. Solo: Cakra Books.

Soekanto, S \& Mamudji, S. (1985). Penelitian Hukum Normatif Suatu Tinjauan Singkat. Jakarta, Indonesia: RajaGrafindo Persada.

\section{Jurnal}

Adiwijana, M.R. (2020). Pembebanan Pembuktian Dalam Tindak Pidana Pencucian Uang. Media Iuris, 3(1), 75-88.

Aziz, A.S. (2018). Rekonseptualisasi Tafsir Asas Praduga Tak Bersalah. IQTISAD, $4(1), 1-26$.

Chandra, et all. (1016). Kedudukan Tindak Pidana Asal (Predicate Crime) Dalam Pembuktian Tindak Pidana Pencucian Uang. Jurnal Paradigma Hukum Pembangunan, 1(2), 153-169. Retrieved from http://ejournal.atmajaya.ac.id/index.php/paradigma/article/view/1727.

Dewi, Ayu K.S.M, \& Puspawati. (2012). Penerapan Sistem Pembuktian Terbalik Terhadap Tindak Pidana Korupsi (Sebuah Upaya Progresif Dalam Pemberantasan Tindak Pidana Korupsi). Yustisia Jurnal Hukum 1(2), 1-5.

Eddyono, S.W. (2011). Verification Reversed Imposition and It's Challenges. Jurnal Legislasi Indonesia 8(2), 267-280. Retrieved from https://ejurnal.peraturan.go.id/index.php/jli/article/view/358.

Endraswari, A.A.M. (2016). Penerapan Beban Pembuktian Terbalik Dalam Perampasan Illicit Enrichment Kaitannya Dengan Hak Asasi Manusia. Jurnal Magister Hukum Udayana (Udayana Master Law Journal), 5(2), 392-405.

European Union, and The Council of Europe. (2013). Impact Study on Civil Forfeiture. Council of Europe.

Hanafi. (2013). The Internationalization Of Anti-Money Laundering and The Compliance Of States. Jurnal Hukum IUS QUIA IUSTUM 20(3), 343-361.

Kordos, M. \& Vojtovic, S. (2016). Transnational Corporations in the Global World 
Economic Environment. Procedia - Social and Behavioral Sciences 230, 150158.

Krisnamurti, H. (2015). Pembuktian Tindak Pidana Pencucian Uang (Money Laundering). Wacana Paramarta Jurnal Ilmu Hukum 12(1), 1-12. Retrieved from http://paramarta.web.id/index.php/paramarta/article/view/2.

Lasmadi, S. \& Sudarti, E. (2021). Pembuktian Terbalik Pada Tindak Pidana Pencucian Uang. Refleksi Hukum: Jurnal Ilmu Hukum 5(2), 199-218.

Latifah, M. (2015). Urgensi Pembentukan Undang-Undang Perampasan Aset Hasil Tindak Pidana Di Indonesia. Negara Hukum: Membangun Hukum untuk Keadilan dan Kesejahteraan 6(1), 17-30.

Listiyanto, A. (2017). Pembaharuan Sistem Hukum Acara Pidana. Rechtsvinding, 1-4. Retrieved from https://rechtsvinding.bphn.go.id/view/view_online.php?id=234.

Mentari, K.P., et all. (2019). Urgensi Asas Presumption Of Guilt Dalam Upaya Pencegahan Dan Pemberantasan Tindak Pidana Pencucian Uang. Kertha Wicara 8(4), 1-14. Retrieved from https://ojs.unud.ac.id/index.php/kerthawicara/article/view/50896.

Mulyadi, L. (2015). Asas Pembalikan Beban Pembuktian Terhadap Tindak Pidana Korupsi Dalam Sistem Hukum Pidana Indonesia Dihubungkan Dengan Konvensi Perserikatan Bangsa-Bangsa Anti Korupsi 2003. Jurnal Hukum dan Peradilan 4(1), 101-132.

Nasution, E.S. (2015). Pertanggungjawaban Pidana Korporasi Dalam Tindak Pidana Pencucian Uang. Jurnal Mercatoria 8(2), 132-144.

Nurhasan. (2017). Keberadaan Asas Praduga Tak Bersalah Pada Proses Peradilan Pidana: Kajian. Jurnal Ilmiah Universitas Batanghari Jambi 17(3), 205-215.

Perbawa, I Ketut Sukawati L. P. (2015). Tindak Pidana Pencucian Uang Dalam Sistem Perbankan Indonesia. Jurnal Advokasi 5(1), 41-57. Retrieved from https://www.neliti.com/publications/29394/tindak-pidana-pencucian-uangdalam-sistem-perbankan-indonesia.

Prasetia, M. Edo Rezawan, et all. (2014). Sistem Pembuktian Terbalik Dalam Pembuktian Perkara Gratifikasi. Verstek 2(2), 183-195. Retrieved from https://jurnal.uns.ac.id/verstek/article/view/38863.

Pusat Pelaporan dan Analisis Transaksi Keuangan. (2020). Buletin Statistik Tahun 2020 Anti Pencucian Uang Dan Pencegahan Pendanaan Terorisme. Retrieved from https://www.ppatk.go.id/publikasi/read/120/buletin-statistikapuppt-vol-124---juni-2020.html.

Raihan, F. \& Sulistiowati, N. (2021). Kebebasan Pencucian Uang Dipengaruhi Oleh Keahlian Pidana Menguasai : Placement, Layering, Dan Integration (Suatu Kajian Studi Literatur Manajemen Sumberdaya Manusia). Jemsi: Jurnal Ekonomi Manajemen Sistem Informasi 2(6), 694-701.

Satria, H. (2017). Ke Arah Pergeseran Beban Pembuktian. Integritas Jurnal Anti Korupsi 3(1), 87-114.

Setiyono. (2007). Eksistensi Saksi Mahkota Sebagai Alat Bukti Dalam Perkara Pidana." Lex Jurnalica 5(1), 29-37. Retrieved from https://ejurnal.esaunggul.ac.id/index.php/Lex/article/view/272.

Setyawati, I.A. (2014). Beban Pembuktian Terbalik Dalam Perkara Money Laundering Dengan Predicate Crime Tindak Pidana Korupsi. 1-19. Retrieved from http://hukum.studentjournal.ub.ac.id/index.php/hukum/article/view/375.

Smith, B.P. (2005). The Presumption of Guilt and the English Law of Theft, 17501850. Law and History Review 23(1), 133-171.

Supriyanta. (2003). Perkembangan Sistem Peradilan Pidana. Wacana Hukum 2(4), 
$1-9$.

Tambunan, M.P. (2016). Pertanggungjawaban Pidana Korporasi Dalam Tindak Pidana Pencucian Uang. Mimbar Keadilan 8(2), 111-128.

Tiwari, M., et all. (2020). A Review of Money Laundering Literature: The State of Research in Key Areas. Pacific Accounting Review 32(2), 271-303.

Wangga, M.S.E. (2012). Mekanisme Pembalikan Beban Pembuktian Tindak Pidana Pencucian Uang. Jurnal Hukum 3(2), 333-352.

Wijaksana, Muhamad Mahrus Setia. (2020). Ajaran Pertanggungjawaban Pidana Korporasi Dalam Perspektif Tindak Pidana Pencucian Uang. Jurnal RechtsVinding: Media Pembinaan Hukum Nasional, 1-6. Retrieved from https://rechtsvinding.bphn.go.id/jurnal_online/AJARAN PJP KORPORASI TPPU.pdf.

\section{Artikel}

Bisnis.com. (2020). Hari Antikorupsi: Total Kerugian Negara Sejak 2018 Capai Rp7,62 Triliun. Retrieved from https://kabar24.bisnis.com/read/20201210/15/1328940/hari-antikorupsi-totalkerugian-negara-sejak-2018-capai-rp762-triliun\#: :text=Jumlah. Diakses pada 12 Juli 2021.

Komisi Pemberantasan Korupsi. (2021). Statistik TPK Berdasarkan Jenis Perkara. Retrieved from https://www.kpk.go.id/id/statistik/penindakan/tpkberdasarkan-jenis-perkara. Diakses pada 23 September 2021.

Rastika, I. (2013). Irjen Djoko Susilo Divonis 10 Tahun Penjara, Denda Rp 500 Juta. Kompas.Com. Retrieved from https://nasional.kompas.com/read/2013/09/03/1620347/Irjen.Djoko.Susilo. Divonis.10.Tahun.Penjara.Denda.Rp.500.Juta?page=all. Diakses pada 28 September 2021

\section{Skripsi}

Julita. (2021). Strategi Pencegahan Money Laundering Melalui Know Your Customer Principles Pada Bank Muamalat Cabang Purwokerto." IAIN Purwokerto. Retrieved from http://repository.iainpurwokerto.ac.id/9450/.

\section{Laporan}

Ramelan, et al. (2012). Laporan Akhir Naskah Akademik Rancangan UndangUndang Tentang Perampasan Aset Tindak Pidana. Indonesia, 2012. Retrieved from https://bphn.go.id/data/documents/na_ruu_tentang_perampasan_aset.pdf 